\title{
Myxoinflammatory fibroblastic sarcoma of the submandibular gland
}

\section{Submandibüler bez yerleşimli miksoenflamatuvar fibroblastik sarkom}

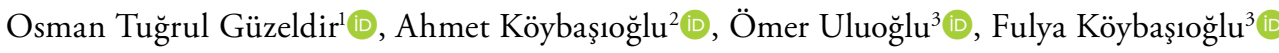 \\ ${ }^{1}$ Department of Audiology, Istanbul Health and Technology University, Istanbul, Turkey \\ ${ }^{2}$ Department of Otolaryngology, Ankara Koru Hospital, Ankara, Turkey \\ ${ }^{3}$ Department of Pathology, Ankara Yüksek Ihtisas University, Ankara, Turkey
}

\begin{abstract}
Myxoinflammatory fibroblastic sarcoma (MIFS) is a rare low-grade soft tissue tumor, it usually affecting the distal extremities. Upon conducting a literature review, we could not find a case of MIFS in the submandibular gland. In this study, we described a 44-year-old female patient who presented to our clinic with a complaint of swelling under the left side of her submandibular region that had persisted for eight months. Due to an initial diagnosis of submandibular gland neoplasm, the gland was totally excised. The pathological examination report indicated MIFS, and therefore, the patient was recommended to attend periodic follow-up visits.
\end{abstract}

Keywords: Myxoinflammatory fibroblastic sarcoma, sarcoma, submandibular gland.

Myxoinflammatory fibroblastic sarcoma (MIFS) is a rare tumor of soft tissues which usually affects the distal extremities. The possibility of local recurrence is high, whereas distant metastasis is rare. ${ }^{[1]}$ Although some reports state that it is more prevalent in males, the prevalence is equal in both sexes, and it is more frequent between the ages of $40-50 .{ }^{[2]}$ There is no known predisposing factor, although a history of trauma is common. ${ }^{[3]}$ On magnetic resonance imaging (MRI), most lesions have low signal on T1-weighted
$\ddot{O} Z$

Miksoenflmatuvar fibroblastik sarkom (MIFS) genellikle distal ekstremiteleri etkileyen ve ender görülen düşük gradeli yumuşak doku tümörüdür. Yaptığımız literatür taramasında submandibüler bez yerleşimli bir MIFS olgusuna rastlanmamıştır. Bu makalede sekiz aydır süregelen sol submandibüler bölgede şişlik şikayeti ile kliniğimize başvuran 44 yaşında kadın hasta sunuldu. Submandibüler bez neoplazmı ön tanısıyla bez total olarak eksize edildi. Patolojik inceleme sonucu MIFS ile uyumlu olması üzerine hastaya periyodik kontrollerle takip önerildi.

Anahtar sözcükler: Miksoenflamatuvar fibroblastik sarkom, sarkom, submandibüler bez.

images and high signal on T2-weighted images. Most notable is the variable post-contrast enhancement. ${ }^{[4]}$ The best approach involves a large resection, follow-up, and a systemic oncological examination with workups including the chest to detect any metastasis. ${ }^{[5]}$

\section{CASE REPORT}

A 44-year-old female patient presented to our clinic with painless swelling under the left side of

Received: April 19, 2021 Accepted: November 23, 2021 Published online: February 25, 2022

Correspondence: Osman Tuğrul Güzeldir, MD. Özel Koru Hastanesi, 06510 Çankaya, Ankara, Türkiye e-mail: drotg83@gmail.com 


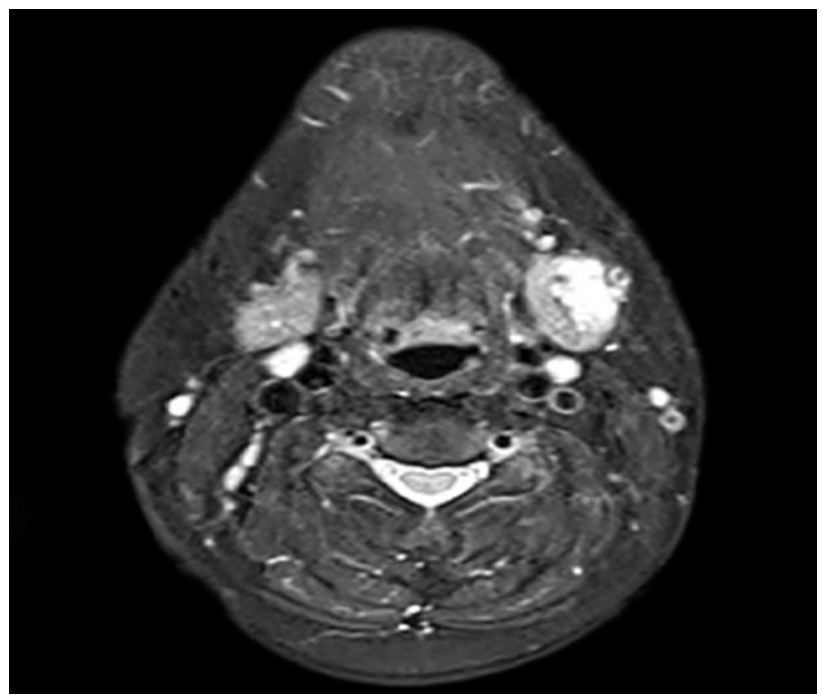

Figure 1. Appearance of the lesion in T1A magnetic resonance imaging sequence.
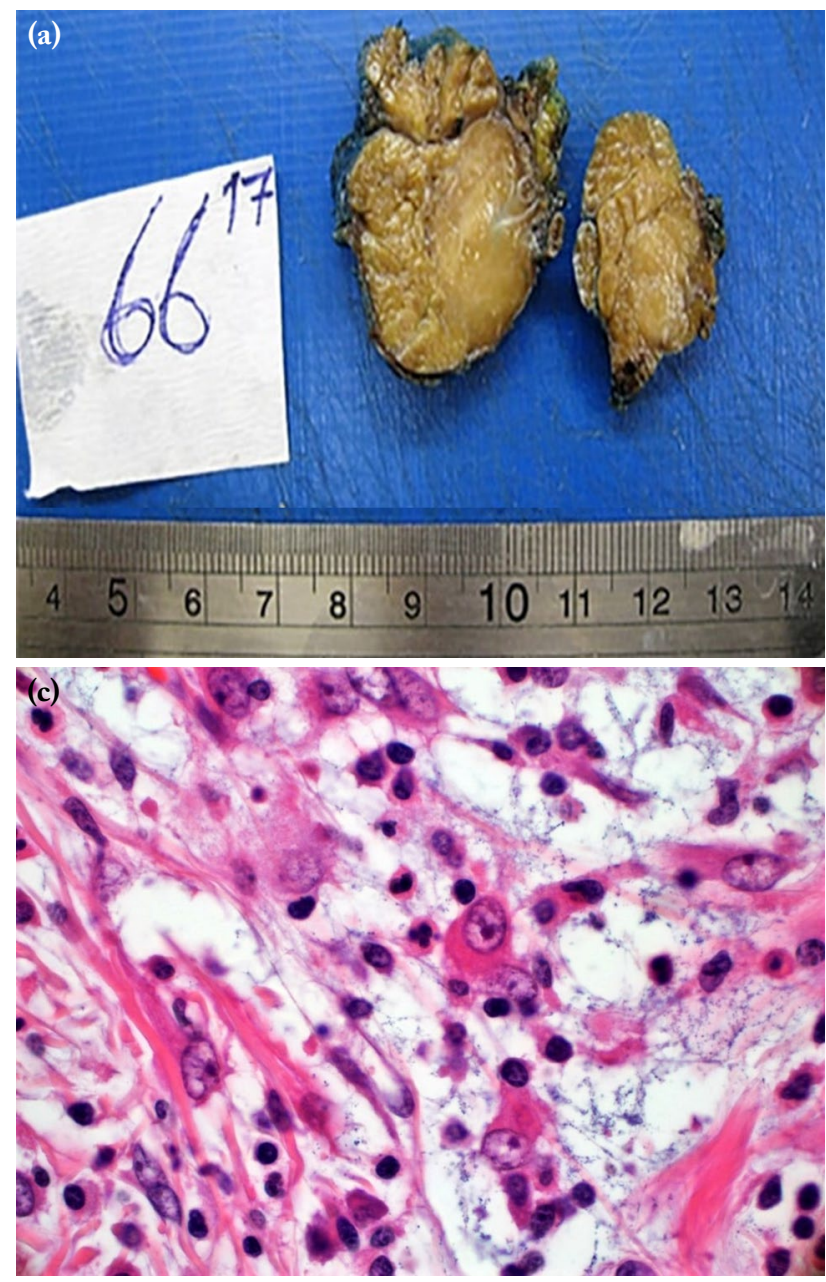

Figure 3. (a) Macroscopic appearance of the tumor. (b) Tumor infiltration in the salivary gland lobule (HEX 5×/0.15-Zeiss). (c) Atypical epithelioid ganglion-like cells, which are often described as Reed-Sternberg-like cells or virocytes (HEX 100×/1.25 oil-Zeiss) (d) Tumors comprise moderately cellular nodules of basophilic myxoid material alternating with fibrohyaline and focally hemorrhagic stroma, as well as a prominent mixed acute and chronic inflammatory cell infiltrate rich in eosinophils, neutrophils, lymphocytes, and plasma cells.

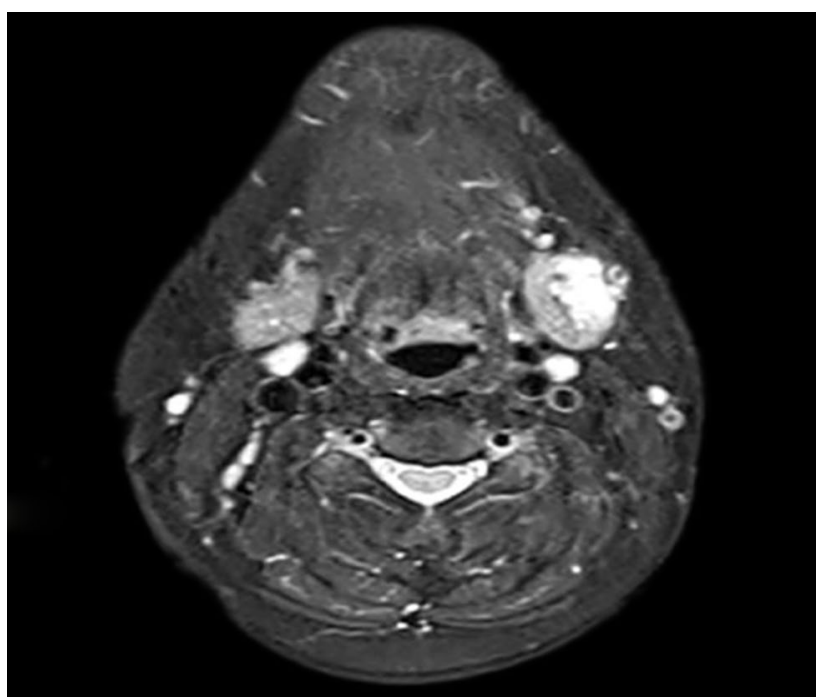

Figure 2. Appearance of the lesion in T2A magnetic resonance imaging sequence.
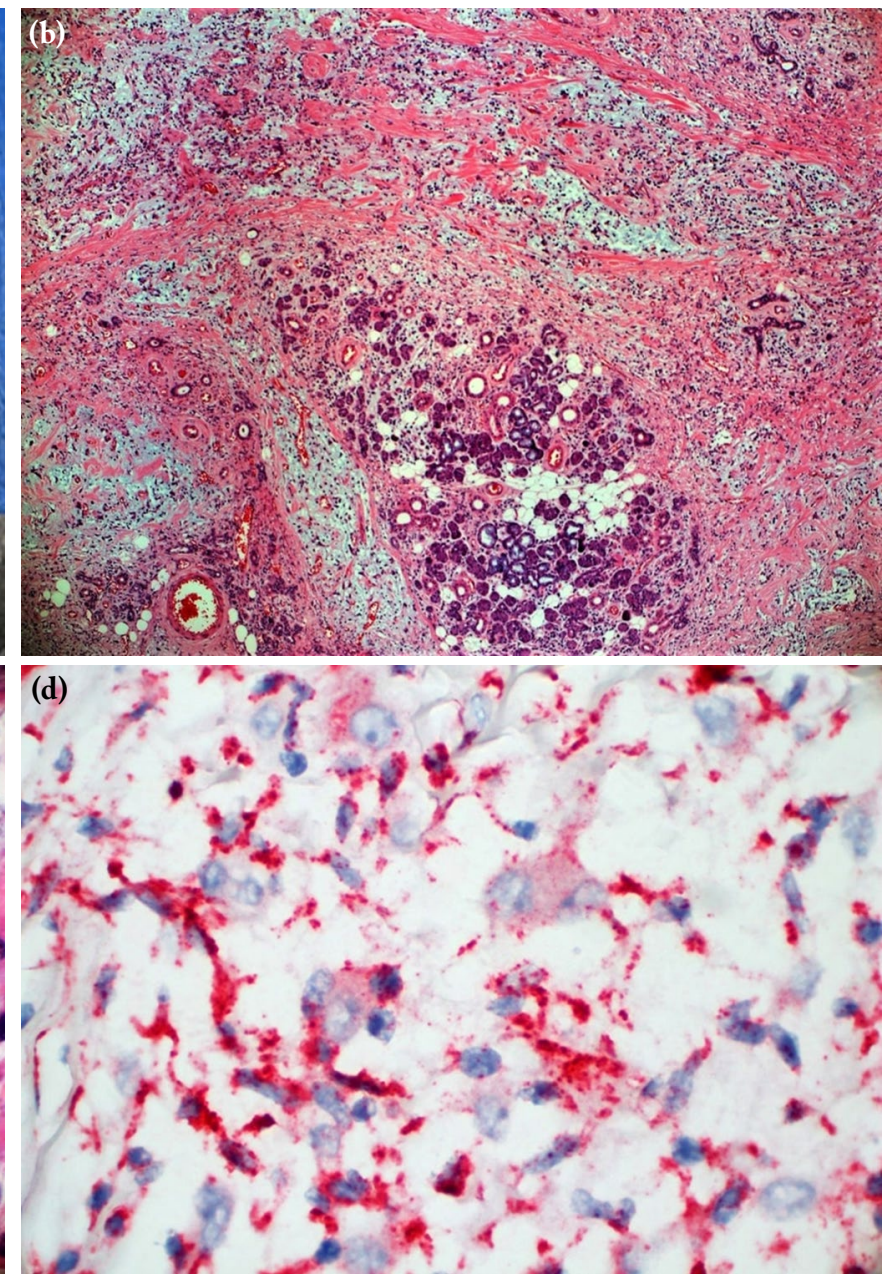
her submandibular region that started approximately eight months before. The patient was presented to our clinic with the diagnosis of submandibular calculus. The patient's medical history included mastectomy, chemotherapy, and radiotherapy due to breast cancer. In the physical examination, there was a mass lesion approximately $2 \times 2 \mathrm{~cm}$ in size in the left submandibular gland.

In the MRI of the neck performed in an external center, a lobulated contoured lesion with heterogeneous contrast uptake following intravenous contrast material administration was observed in the lateral half of the left submandibular gland, which had a size of $1.8 \times 1.2 \times 1.6 \mathrm{~cm}$ at its widest part and had a hypointense appearance in $\mathrm{T} 1 \mathrm{~A}$ sequences and a hyperintense appearance in $\mathrm{T} 2 \mathrm{~A}$ sequences. There was mild diffusion restriction at the medial part of the lesion (Figures 1 and 2).

The patient underwent left submandibular gland excision in our clinic due to an initial diagnosis of left submandibular gland mass. The tissue specimen sent for pathological examination had a size of $4.5 \times 3.5 \times 2.5 \mathrm{~cm}$. Serial sections applied to the largest specimen revealed a $2.5 \times 1.6 \times 2.2 \mathrm{~cm}$ homogeneous nodular structure with areas in which yellow and white intermix. In the microscopical examination, there was inflammation rich in plasmocytes in the myxoid and hyalinized areas. Cells with profound eosinophilic nucleoli and large eosinophilic cytoplasm, bundles of spindle-like cells, and low mitotic activity were observed (Figure 3.a-d).

\section{DISCUSSION}

Myxoinflammatory fibroblastic sarcoma is a rare soft tissue sarcoma generally observed in acral parts of the body. Soft tissue sarcomas are less frequent in the head and neck region and often present a challenge in terms of diagnosis. It is usually located at the distal ends of the extremities. It has also been reported in the trunk, proximal extremities, and neck area. There are some reports of cases that involve the face and scalp. ${ }^{[3]}$

This type of sarcoma was first described at the end of 1990 's by Montgomery et al. ${ }^{[2]}$ During the same period, Meis-Kindblom ${ }^{[6]}$ defined it as acral myxoinflammatory fibroblastic sarcoma. Myxoinflammatory fibroblastic sarcoma was accepted by World Health Organization (WHO) in 2002.[1-3]

Montgomery et al. ${ }^{[2]}$ defined it as an "inflammatory myxohyaline tumor" of the distal extremities containing virocytes or Reed-Sternberg-like cells, Michal et al. ${ }^{[7]}$ defined it as an "inflammatory myxoid tumor" of the soft tissue containing bizarre giant cells, and Meis-Kindblom and Kindblom ${ }^{[6]}$ defined it as acral myxoinflammatory fibroblastic sarcoma. ${ }^{[1]}$

The prevalence is equal in both sexes, and it is more frequent over the age of 40 . There is no known predisposing factor, although a history of trauma is common. ${ }^{[2]}$ Myxoinflammatory fibroblastic sarcoma manifests as a painless, slowly growing mass over six weeks to 20 years. Lesions are generally small, usually between 1 and $10 \mathrm{~cm}$. The tumor essentially originates from the soft tissues and grows with an infiltrative pattern. It may cause ulceration superficially in the dermis, subcutis, and epidermis or grow into the deep fascia or tendon sheath. ${ }^{[1,6,9]}$

Involvement of acral areas (hands, fingers, feet, popliteal fossa) is frequent. The upper extremities are more frequently affected than the lower extremities. Reported non-acral sites include the scalp, neck, shoulder, chest wall, trunk, and proximal parts of the upper and lower extremities. ${ }^{[2]}$ For the first time in 2015, MIFS was reported in the scalp of an 80-year-old male. ${ }^{[8-10]}$ We could not find a case of MIFS in the submandibular gland upon conducting a literature review.

We decided to share our experience as the disease should be considered in the differential diagnosis of head and neck tumors although it is rare. Pathologically, MIFS has a grey-white, multinodular, infiltrative, and myxoid appearance. There are three morphologically distinct types of neoplastic cells that are scattered as single cells or cluster in nodules. The first is spindle to epithelioid cells with moderate degrees of nuclear atypia. The second type of cell is large, atypical epithelioid ganglion-like cells, often described as Reed-Sternberg-like cells or virocytes, which can be mononucleate, binucleate, or sometimes multinucleate, with prominent large eosinophilic nucleoli, vesicular nuclei, occasional perinuclear halos, and abundant amphophilic cytoplasm. The third type is called pseudolipoblasts, atypical cells with compressed nuclei and abundant vacuolated myxoid basophilic cytoplasm containing extracellular mucinous material. Hemosiderin deposition, Touton-type giant cells, and emperipolesis, an occasionally dominant feature, can be present. ${ }^{[11-13]}$

Diagnostically, MIFS can be confused with tumors that have high metastatic potential and reactive fibroinflammatory (infectious and inflammatory) processes. Therefore, the differential diagnosis should include conditions such as myxoid malignant fibrous histiocytoma, ganglion cysts, tenosynovitis, and spindle cell tumor. Malignant fibrous histiocytoma 
and liposarcoma contain myxoid focus and dispersed multivacuolated cells, and therefore they may cause confusion. ${ }^{[14]}$

Myxoinflammatory fibroblastic sarcoma is a malignant situation that can exhibit local recurrence. Regional recurrence rates have been reported to be between $22 \%$ and $67 \%$ within three months to five years. Distant metastasis occurs in less than $2 \%$. Distant metastases generally occur in the inguinal lymph nodes, lungs, and livers, but mortality rates are substantially low. ${ }^{[14,15]}$

There is no known clinical or pathological parameter that could be used to determine the biological behavior of the tumor. The best approach involves a large resection, follow-up, and a systemic oncological examination with workups including the chest to detect any metastasis. ${ }^{[16]}$ Some authors recommend control examinations once every three months during the first two years and once every six months during the rest of the five-year period. ${ }^{[17]}$

Tumor necrosis has been observed in patients who receive preoperative radiotherapy; therefore, chemotherapy is generally recommended in addition to radiotherapy in case of multiple local recurrences and metastatic disease. ${ }^{[17]}$

In conclusion, although it is rarely encountered, MIFS of the submandibular gland should be considered in the differential diagnosis of head and neck tumors.

\section{Declaration of conflicting interests}

The authors declared no conflicts of interest with respect to the authorship and/or publication of this article.

\section{Funding}

The authors received no financial support for the research and/or authorship of this article.

\section{REFERENCES}

1. Ieremia E, Thway K. Myxoinflammatory fibroblastic sarcoma: Morphologic and genetic updates. Arch Pathol Lab Med 2014;138:1406-11.

2. Montgomery EA, Devaney KO, Giordano TJ, Weiss SW. Inflammatory myxohyaline tumor of distal extremities with virocyte or Reed-Sternberg-like cells: A distinctive lesion with features simulating inflammatory conditions, Hodgkin's disease, and various sarcomas. Mod Pathol 1998;11:384-91.

3. Flooks R, Vanacker A, Van Dorpe J, Smet B, Vandewiele I, De Schoenmakere G, et al. Acral myxoinflammatory fibroblastic sarcoma in a renal transplant patient: A case report. Transplant Proc 2009;41:3437-9.

4. Gaetke-Udager K, Yablon CM, Lucas DR, Morag Y. Myxoinflammatory fibroblastic sarcoma: Spectrum of disease and imaging presentation. Skeletal Radiol 2016;45:347-56.

5. Monson E, Vancourt R, Dawson J. Myxoinflammatory fibroblastic sarcoma: A case report and review of the literature. J Foot Ankle Surg 2010;49:86.e1-3.

6. Meis-Kindblom JM, Kindblom LG. Acral myxoinflammatory fibroblastic sarcoma: A lowgrade tumor of the hands and feet. Am J Surg Pathol 1998;22:911-24.

7. Michael M, Dmitry V, Ladislav H, Zdenek K, Naoto K, Michal M. High-grade myxoinflammatory fibroblastic sarcoma: a report of 23 cases. Ann Diagn Pathol 2015;19:157-63.

8. Fletcher CDM, Unni KK, Mertens F. World Health Organization, International Agency for Research on Cancer. In: Pathology and genetics of tumours of soft tissue and bone. Lyon: IARC Press; 2002.

9. Kobayashi E, Kawai A, Endo M, Suehara Y, Takeda K, Nakatani F, et al. Myxoinflammatory fibroblastic sarcoma. J Orthop Sci 2008;13:566-71.

10. Meis JM, Kindblom LG, Mertens F. Myxoinflammatory fibroblastic sarcoma. In: Fletcher CDM, Bridge JA, Hogendoorn PCW, Mertens F, editors. WHO Classification of Tumours of Soft Tissue and Bone. 4th ed. Lyon: International Agency for Research on Cancer; 2013. p. 87-8.

11. Vroobel K, Miah A, Fisher C, Thway K. Myxoinflammatory fibroblastic sarcoma of the scalp: Aggressive behavior at a rare, nonextremity site. Int J Surg Pathol 2015;23:292-7.

12. Sakaki M, Hirokawa M, Wakatsuki S, Sano T, Endo K, Fujii Y, et al. Acral myxoinflammatory fibroblastic sarcoma: A report of five cases and review of the literature. Virchows Arch 2003;442:25-30.

13. Hassanein AM, Atkinson SP, Al-Quran SZ, Jain SM, Reith JD. Acral myxoinflammatory fibroblastic sarcomas: Are they all low-grade neoplasms? J Cutan Pathol 2008;35:186-91.

14. Kato M, Tanaka T, Ohno T. Myxoinflammatory fibroblastic sarcoma: A radiographical, pathological, and immunohistochemical report of rare malignancy. Case Rep Orthop 2015;2015:620923.

15. Kinkor Z, Mukensnabl P, Michal M. Inflammatory myxohyaline tumor with massive emperipolesis. Pathol Res Pract 2002;198:639-42.

16. Lang JE, Dodd L, Martinez S, Brigman BE. Case reports: Acral myxoinflammatory fibroblastic sarcoma: A report of five cases and literature review. Clin Orthop Relat Res 2006;445:254-60.

17. Baumhoer D, Glatz K, Schulten HJ, Füzesi L, Fricker R, Kettelhack C, et al. Myxoinflammatory fibroblastic sarcoma: Investigations by comparative genomic hybridization of two cases and review of the literature. Virchows Arch 2007;451:923-8. 